\title{
Short-term Response of Breeding Barred Owls to Forestry in a Boreal Mixedwood Forest Landscape
}

\section{Réponse à court terme de Chouettes rayées à l'exploitation forestière dans une forêt boréale mixte}

\author{
Ben T. Olsen $^{1}, \underline{\text { Susan J. Hannon }}{ }^{1}$, and Gordon S. Court ${ }^{2}$
}

\begin{abstract}
Forestry and other activities are increasing in the boreal mixedwood of Alberta, with a concomitant decrease in older forest. The Barred Owl (Strix varia) is an old-growth indicator species in some jurisdictions in North America. Hence, we radio-tagged Barred Owls in boreal mixedwood in Alberta to determine whether harvesting influenced habitat selection. We used three spatial scales: nest sites, i.e., nest tree and adjacent area of $11.7 \mathrm{~m}$ radius around nests, nesting territory of $1000 \mathrm{~m}$ radius around nests, and home range locations within $2000 \mathrm{~m}$ radius of the home range center. Barred Owls nested primarily in balsam poplar (Populus balsamifera) snags $>34 \mathrm{~cm}$ dbh and nest trees were surrounded by large, $>34$ $\mathrm{cm} \mathrm{dbh}$, balsam poplar trees and snags. Nesting territories contained a variety of habitats including young $<80$-yr-old, deciduous-dominated stands, old deciduous and coniferous-dominated stands, treed bogs, and recent clear-cuts. However, when compared to available habitat in the study area, they were more likely to contain old conifer-dominated stands and recent cutblocks. We assumed this is because all of the recent harvest occurred in old stands, habitat preferred by the owls. When compared with random sites, locations used for foraging and roosting at the home range scale were more likely to be in young deciduous-dominated stands, old conifer-dominated stands and cutblocks > $30 \mathrm{yr}$ old, and less likely to occur in old deciduousdominated stands and recent cutblocks. Hence, although recent clearcuts occurred in territories, birds avoided these microhabitats during foraging. To meet the breeding requirements of Barred Owls in managed forests, 10-20 ha patches of old deciduous and mixedwood forest containing large Populus snags or trees should be maintained. In our study area, nest trees had a minimum dbh of $34 \mathrm{~cm}$. Although cut areas were incorporated into home ranges, the amount logged was low, i.e., 7\%, in our area. Hence more research is required to determine harvest levels tolerated by owls over the long term.
\end{abstract}

RÉSUMÉ. L'exploitation forestière et d'autres activités humaines s'intensifient dans la forêt boréale mixte de l'Alberta et la superficie de forêt ancienne diminue en conséquence. La Chouette rayée (Strix varia) est considérée comme étant une espèce indicatrice de forêts anciennes dans certaines provinces ou États de l'Amérique du Nord. Nous avons donc posé des radio-émetteurs à des Chouettes rayées dans la forêt boréale mixte de l'Alberta afin de déterminer si l'exploitation forestière a une incidence sur la sélection de l'habitat. Nous avons travaillé à trois échelles spatiales : l'emplacement du nid, c'est à dire l'arbre où il se trouve et l'espace environnant (rayon de 11,7 m), le territoire de nidification (rayon de $1000 \mathrm{~m}$ autour du nid) et les emplacements occupés dans le domaine vital (rayon de $2000 \mathrm{~m}$ à partir du centre de ce domaine). Les Chouettes rayées ont niché principalement dans des chicots de peuplier baumier (Populus balsamifera) de $>34 \mathrm{~cm}$ de diamètre à hauteur de poitrine (dhp) et les arbres abritant le nid étaient entourés de grands peupliers baumiers et de chicots de $>34 \mathrm{~cm}$ dhp. Les territoires de nidification renfermaient divers habitats dont des jeunes peuplements de $<80$ ans à dominance de feuillus, des vieux peuplements à dominance de feuillus ou de conifères, des tourbières forestières et des coupes à blanc récentes. Cependant, comparés

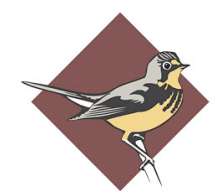

BIRD STUDIES CANADA 
aux habitats disponibles dans la zone d'étude, ces territoires étaient plus susceptibles de contenir des vieux peuplements à dominance de conifères et des blocs de coupe récents. Nous avons supposé que cette situation était due au fait que toutes les coupes récentes ont eu lieu dans des vieux peuplements, l'habitat préféré des chouettes. Comparés à des sites choisis au hasard, les endroits utilisés pour l'alimentation ou le repos dans le domaine vital étaient plus susceptibles de se trouver dans de jeunes peuplements à dominance de feuillus, des vieux peuplements à dominance de conifères et des blocs de coupe de > 30 ans et moins susceptibles d'être situés dans de vieux peuplements à dominance de feuillus ou des blocs de coupe récents. Par conséquent, bien que des coupes à blanc aient eu lieu récemment dans les territoires, les oiseaux évitent ces microhabitats lorsqu'ils s'alimentent. Pour satisfaire les exigences de la Chouette rayée en matière de nidification dans les forêts aménagées, il faudrait maintenir des parcelles de forêt caducifoliée et de forêt mixte ancienne d'une superficie de 10-20 ha contenant des peupliers ou des chicots de grande taille. Dans notre aire d'étude, les nids étaient situés dans des arbres d'au moins $34 \mathrm{~cm}$ de dhp. Bien que des superficies coupées soient inclues dans les domaines vitaux, la superficie exploitée dans cette zone était faible, soit $7 \%$. Toutefois, d'autres études seront nécessaires afin de déterminer l'intensité de coupe tolérée à long terme par cette espèce.

Key Words: Barred Owl; boreal mixedwood forest; habitat selection; Strix varia.

\section{INTRODUCTION}

Based on its large home range, association with older forest, and preference for large unfragmented blocks of forest (Mazur and James 2000), the Barred Owl has been promoted as an indicator species of old growth for use in land planning and habitat conservation in some regions (James 1993, Hess and King 2002, Rubino and Hess 2003). Resource extraction by the forestry and energy sectors will have a major impact on the age structure and composition of boreal forest in northern Alberta (Schneider et al. 2003). Reductions in the amount of old-growth forest are predicted, resulting in a concomitant decline of habitat for species that use older forest and the structures within (Cumming et al. 1994). Some forestry companies retain residual features of older forest, i.e., trees, snags, downed woody material, within cutblocks as habitat for wildlife. Cavity nesting owls are presumed to benefit from such practices, yet the habitat requirements of many species, including Barred Owls, are not known for this region (Kirk and Hyslop 1998).

Habitat associations of Barred Owls have been described in a variety of forest ecosystems (reviewed in Mazur and James 2000). In eastern deciduous forests, they are typically found in mature and old, mixedwood swamps and riparian areas (Nicholls and Warner 1972, Elody and Sloan 1985, Bosakowski et al. 1987). In boreal forest of
Saskatchewan (Mazur et al. 1998) and foothills forest in western Alberta (Takats 1998), Barred Owls selected old mixedwood (white spruce (Picea glauca) and trembling aspen (Populus tremuloides), aspen, and balsam poplar forest. In Saskatchewan, they avoided young $<50 \mathrm{yr}$ forest in both the breeding and nonbreeding seasons and at the scale of individual locations and home ranges (Mazur et al. 1998). Mature, old hardwood and mixedwood forests are occupied because suitable nesting sites in large diameter trees and snags are most abundant there (Haney 1997, Postupalsky et al. 1997) and because the structural complexity of habitats may provide a diversity of prey (Mazur et al. 1998). In the Pacific Northwest, however, Barred Owls have displaced Northern Spotted Owls (Strix occidentalis), a federally endangered species (Olson et al. 2005), by expanding into landscapes that have been partly harvested (Dark et al. 1998, Herter and Hicks 2000, Kelly et al. 2003). This suggests that they are more tolerant of habitat loss and stand age heterogeneity than Spotted Owls.

In this paper we examine habitat selection by Barred Owls in old mixedwood boreal forest in Alberta, parts of which had been recently harvested, to determine whether they avoided cutblocks and to provide information on their habitat requirements in this area. We examined Barred Owl habitat selection at three spatial scales, analogous to the second, third, and fourth orders of habitat selection described by Johnson (1980). First we examined 
nest site selection by measuring vegetation structure and composition at Barred Owl nests and close surroundings (0.04 ha). Second, we compared forest cover in the nesting territory, $1000 \mathrm{~m}$ radius around nest sites, with that on unused portions of the landscape in the study area. Finally, we examined Barred Owl radio telemetry locations within home ranges, i.e., $2000 \mathrm{~m}$ radius around home range centers, relative to forest composition provided by vegetation inventory used by foresters. Based on other studies of Barred Owl habitat, we expected owls to select for older forest and avoid recent cutblocks.

\section{METHODS}

\section{Study area}

The study was conducted between 1994 and 1998 on an $800 \mathrm{~km}^{2}$ area in north-central Alberta near Calling Lake $\left(55^{\circ} 15^{\prime} \mathrm{N}, 113^{\circ} 19^{\prime} \mathrm{W}\right)$. The study area is located in the boreal mixedwood ecoregion (Strong and Leggat 1992) and was chosen to be large enough to encompass the territories of several owls, but be small enough to facilitate the logistics of tracking owls under difficult field conditions. Forest stands are comprised of trembling aspen, balsam poplar, white spruce, jack pine (Pinus banksiana Lamb.), black spruce (Picea mariana (Mill.) BSP), and tamarack (Larix laricina (Du Roi) K. Koch). White birch (Betula papyrifera Marsh.) and balsam fir (Abies balsamea (L.) Mill.) are also common in the subcanopy or as minor components in the canopy. Tree age and species composition heterogeneity is maintained by differences in topography and drainage, fires and defoliating insect outbreaks (Bonan and Shugart 1989).

Harvesting occurred in upland areas of mature and old forest of Populus, white spruce, or mixedwood prior to the study. Deciduous trees supply pulp mills and conifers are harvested primarily for sawmills. Trees were harvested using clear-cutting in a two pass system, with 5-20\% of live and dead trees retained on cutblocks. The first pass of harvesting occurred in 1993 and 1994, however some areas had been clear-cut approximately $30 \mathrm{yr}$ ago. In a 100 $\mathrm{km}^{2}$ section of the study area an experimental study examining the effects of forest fragmentation on boreal birds has been ongoing since 1993 (Schmiegelow and Hannon 1993, Schmiegelow et al. 1997). Here, forest reserves of 1-100 ha were left surrounded by $200 \mathrm{~m}$ of harvest. Approximately
$7 \%$ of the total landscape had been recently harvested.

\section{Location and capture of owls}

To find Barred Owl territories, we played taped calls of owls at 52 stations spaced at 2-km intervals along logging roads and seismic lines once per year from January to March. A tape of owl calls and intermittent silent periods was broadcast in all directions for 25 minutes on a SONY CFS-914 cassette player. Because owls respond to conspecifics and other species (Bosakowski and Smith 1998), we played calls of the northern sawwhet owl (Aegolius acadicus), boreal owl (Aegolius funereus), Barred Owl, and Great-horned owl (Bubo virginianus). Fifteen adult Barred Owls, including seven males and eight females, were captured using either modified Swedish goshawk traps, hand-held fishing nets at nest cavities or using a live mouse as bait, or mistnetting using a live Barred Owl decoy (Olsen 1999). Owls were banded with a numbered identification ring on the tarsus and fitted with radio transmitters (20 g; Holohil Systems Ltd.) using a backpack made of Teflon strapping (Guetterman et al. 1991).

\section{Radio telemetry}

Radio-collared owls were tracked opportunistically in the spring (April-June) in order to locate nests; and weekly in the summer (July-September). Locations were triangulated to avoid flushing the owl and then estimated using the triangulation software CALHOME (Kie 1994). Triangulations with error polygons greater than 3 ha were rejected. Geographic coordinates for the triangulation positions and nest site locations were taken using a Trimble GeoExplorer ${ }^{\circledR}$ GPS unit. The GPS locations were then differentially corrected using the program PATHFINDER (Trimble Navigation Ltd.) to provide coordinates accurate to $1 \mathrm{~m}$.

\section{Vegetation sampling}

Structural and compositional measures of tree and forest stand characteristics were measured in July and August at owl nest sites $(n=10)$ and three unoccupied but potential nest sites per home range $(n=30)$. We chose 30 unoccupied sites for comparison to try to account for the variation within 
Table 1. Variables and their percent covers derived from the digital Alberta Vegetation Inventory that were used to construct habitat models based on the GIS data layers. Deciduous-dominated and conifer-dominated stands had $>50 \%$ of overstory trees as deciduous species and $>50 \%$ of overstory trees as conifer species, respectively.

\begin{tabular}{|c|c|c|c|}
\hline Name & Abbreviation & Description & $\begin{array}{l}\text { Percent }(\%) \text { of } \\
\text { landscape }\end{array}$ \\
\hline Old deciduous mixedwood & OLDDEC & Deciduous dominated stand with estimated origin $\leq 1910$ & 9.5 \\
\hline Old conifer mixedwood & OLDCON & Conifer dominated stand with estimated origin $\leq 1910$ & 8.4 \\
\hline $\begin{array}{l}\text { Young deciduous } \\
\text { mixedwood }\end{array}$ & YNGDEC & Deciduous dominated stand with estimated origin $>1910$ & 31.5 \\
\hline Young conifer mixedwood & YNGCON & Conifer dominated stand with estimated origin $>1910$ & 1.8 \\
\hline Treed bog & TRBOG & $\begin{array}{l}\text { Black spruce bog, includes tamarack and some birch/ } \\
\text { black spruce mixes }\end{array}$ & 28.4 \\
\hline Pine & PINE & $\begin{array}{l}\text { Pine, includes mixed stands where pine is the dominant } \\
\text { conifer }\end{array}$ & 2.4 \\
\hline Wetland & WETLND & $\begin{array}{l}\text { Muskeg, other wetlands, and miscellaneous natural } \\
\text { nonvegetated types }\end{array}$ & 6.9 \\
\hline Open water & WATER & Water & 2.1 \\
\hline Anthropogenic & ANTHRO & $\begin{array}{l}\text { Anthropogenic features, well sites, clearings, roads, and } \\
\text { pipelines }\end{array}$ & 0.8 \\
\hline Recent cut block & CUT1 & $\begin{array}{l}\text { Harvested blocks }<30 \text { yr, includes partial cuts and } \\
\text { identifiable salvage-logged areas; most were harvested } \\
\text { between } 1993 \text { and } 1994\end{array}$ & 7.3 \\
\hline Older cut block & CUT2 & Older harvested blocks of unknown origin (> $30 \mathrm{yr}$ ) & 0.7 \\
\hline
\end{tabular}

territories without overbalancing our models with unused sites. Unused sites were chosen at random, but at least $200 \mathrm{~m}$ apart, and were centered on a tree or snag with a minimum dbh of $\geq 34 \mathrm{~cm}$ representing a potential cavity tree. At each nest and unused site, vegetation was measured within four plots of radius $11.7 \mathrm{~m}$ and area of 0.04 ha. One plot was centered on the nest or unused site and the others were placed $30 \mathrm{~m}$ away at $120^{\circ}, 240^{\circ}$, and $360^{\circ}$. Vegetation measurements from the subplots were averaged for each site.

The following measurements of the nest tree and unused central tree were made: species, dbh, tree height, cavity height, cavity type, and percent lean.
Cavity type was recorded as side-entrance windowtype cavity, top-entrance chimney-type cavity, or other. Within the 0.04 ha plots, total number of each species of tree and snag in four diameter classes were recorded: 8-15 cm, 15-23 cm, 23-38 cm, and $>38 \mathrm{~cm}$. For coarse woody material, fallen trees $\geq$ $12 \mathrm{~cm} \mathrm{dbh}$, we recorded tree species and length. Tree, snag, and coarse woody material densities were calculated by dividing the total number by the area of the combined plots, i.e., 0.16 ha. Basal area was calculated using the median radii for each diameter class $(5.75 \mathrm{~cm}, 9.5 \mathrm{~cm}, 15.25 \mathrm{~cm}$, and 21.5 $\mathrm{cm})$. Shrubs were sampled within the first $5 \mathrm{~m}$ radius of each 0.008 ha subplot. Species and total number of saplings $<2.5 \mathrm{~cm}$ dbh and poles $2.5-8 \mathrm{~cm} \mathrm{dbh}$ 
Table 2. Means and standard errors of vegetation descriptors at nests $(n=10)$ and random sites $(n=30)$ and range in variables for nest sites. Variables that differ between nests and random sites are in italics. Tree species codes: Aw: Populus tremuloides, Fb: Abies balsamea, Pb: Populus basamifera, Sw: Picea glauca, Sb: Picea mariana.

\begin{tabular}{lcccccc}
\hline \hline Site & Random & \multicolumn{2}{c}{ Nests } & & \\
& Mean & SE & Mean & SE & Range \\
\hline Cavity Tree & & & & & & \\
Diameter at breast height (dbh, cm) & 42.1 & 1.3 & 51.6 & 4.3 & $34-77$ \\
Cavity tree height (m) & 10.8 & 1.3 & 16.0 & 2.6 & $6.5-29.2$ \\
Cavity height (m) & 8.9 & 0.9 & 10.4 & 2.1 & $5.8-26.8$ \\
Cavity tree lean (\%) & 4.1 & 1.9 & 3.8 & 2.0 & $0-21$
\end{tabular}

\section{Overstory Species Composition *}

DBH Class $1(8-15$ cm)

$$
\begin{aligned}
& \text { Aw (stems/ha) } \\
& \mathrm{Pb} \text { (stems/ha) } \\
& \mathrm{Sw} \text { (stems/ha) } \\
& \mathrm{Fb} \text { (stems/ha) }
\end{aligned}
$$

DBH Class $2(15-23 \mathrm{~cm})$

$\begin{array}{lllll}78.6 & 22.4 & 53.9 & 26.2 & 0-239 \\ 36.1 & 12.8 & 20.8 & 14.5 & 0-147 \\ 79.4 & 17.6 & 36.7 & 16.5 & 0-129 \\ 45.9 & 20.1 & 20.8 & 13.8 & 0-123\end{array}$

$\begin{array}{lllll}105.9 & 21.2 & 85.7 & 38.7 & 0-306\end{array}$

$\begin{array}{lllll}55.9 & 10.2 & 52.0 & 18.7 & 0-196\end{array}$

$\begin{array}{lllll}65.7 & 14.0 & 28.8 & 18.7 & 0-190\end{array}$

$\begin{array}{lllll}16.1 & 7.3 & 4.9 & 3.1 & 0-30.6\end{array}$

DBH Class $3(23-38 \mathrm{~cm})$
Aw (stems/ha)
$\mathrm{Pb}$ (stems/ha)
Sw (stems/ha)
$\mathrm{Fb}$ (stems/ha)

73.3

13. 2

51. 4

15. 0

0-141

53.5

12.9

79. 0

20. 4

$0-172$

58. 4

12. 4

30. 6

20. 2

0-196

2. 0

1. 1

6. 7

5. 0

0-49

DBH Class $4(\geq 38 \mathrm{~cm})$
8. 4
1. 6
16. 5
9.4
0-86 
$\mathrm{Pb}$ (stems per ha)

Sw (stems per ha)

\section{Tree Basal Area}

Total deciduous basal area $\left(\mathrm{m}^{2}\right)^{\dagger}$

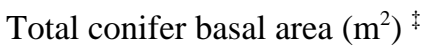

Snag basal area

Aw snag basal area $\left(\mathrm{m}^{2}\right)$

$\mathrm{Pb}$ snag basal area $\left(\mathrm{m}^{2}\right)$

Sw snag basal area $\left(\mathrm{m}^{2}\right)$

\section{Overstory Structure}

Canopy cover $(\%)$

63.1

24. 6

9. 1

84. 7

4. 9

8. 2

1. 0

0. 1

0.9

0. 1

0.2

0.1

0.4

0. 1

0.0

0. 1

0. 0

0.2

0. 1

0. 0

0. 0

0. 0

3.9

68.4

4. 7

39-86

Canopy height (m)

Small deciduous snags (stems/ha) $\S$

Small conifer snags (stems/ha) ${ }^{\S}$

Large deciduous snags (stems/ha) ${ }^{\S}$

Large conifer snags (stems/ha) ${ }^{\S}$

Total snag basal area $\left(\mathrm{m}^{2}\right)$

\section{Understory Structure}

Understory density $($ stems/ha $\times 100) \|$

Shrub height (m)

Small coarse woody material (stems/ha) ${ }^{\mathbb{T}}$

Large coarse woody material (stems/ha) ${ }^{\text {If }}$

Coarse woody material basal area $\left(\mathrm{m}^{2}\right)$

$\begin{array}{ccccc}6.8 & 0.7 & 7.5 & 1.4 & 2.1-17.6 \\ 2.5 & 0.6 & 4.4 & 1.0 & 0-9.2 \\ 108.4 & 9.0 & 104.1 & 17.5 & 36.7-227 \\ 18.0 & 3.7 & 26.3 & 8.6 & 0-79.6 \\ 0.2 & 0.0 & 0.3 & 0.1 & 0-0.6\end{array}$

$\dagger$ Deciduous is the sum of $\mathrm{Pb}$ and $\mathrm{Aw}$

$\$$ Conifer is the sum of $\mathrm{Sw}$ and $\mathrm{Fb}$

$\S$ Small snags are $<34 \mathrm{~cm}$ dbh and large snags are $\geq 34 \mathrm{~cm} \mathrm{dbh}$

$\|$ Understory includes shrubs and trees $<8 \mathrm{~cm}$ dbh

II Small coarse woody material is $<30 \mathrm{~cm}$ dbh and large is $\geq 30 \mathrm{~cm} \mathrm{dbh}$ 
were also recorded. Shrub densities were averaged for each site. Canopy cover in the center plot was measured in each cardinal direction using a spherical densitometer and the four readings were averaged. We also measured the tallest shrub height, subcanopy height, and canopy height using a clinometer.

In order to examine the abundance of potential nest sites within the greater study area, we used data from additional 44 vegetation plots located in mature and old mixedwood stands distributed across the study area. These were plots measured in a similar way from another study on the same landscape (Schmiegelow et al. 1997). We calculated the frequency distribution of snags within each diameter class and compared the density of potential nest sites, i.e., snags $\geq 34 \mathrm{~cm}$ dbh, between nest sites, unused sites, and the greater landscape.

\section{Nest site vegetation analysis}

Variables were tested for normality and nonparametric tests were used for nonnormal data. The number of vegetation descriptors was large (Table 1) compared with the number of dependent variables. We reduced these by conducting independent $t$-tests between nest sites and random points for all measured variables and then choosing those that were significant at $\mathrm{P}<0.10$ in order to be conservative, given our low sample size of nests. This reduced the dataset to five variables: shrub height, total snag basal area, density of large deciduous snags, balsam poplar snag basal area, and density of balsam poplar trees in size class 4 (see Table 1 for units). Since we had no a priori expectations of habitat selection at this scale, we entered these variables into a stepwise binary logistic regression to determine variables that distinguished nest sites and random points within territories. We assessed the predictive accuracy of the model using receiver operating characteristics (ROC) analysis. This analysis determines how accurately a model predicts whether each observation represents presence or absence. Models with area under the curve (AUC) values between 0.5 and 0.7 have poor discrimination capacity; values between 0.7 and 0.9 indicate reasonable discrimination, and rates higher than 0.9 indicate very good discrimination (Swets 1988).

We also compared snag density between nest sites, unused sites, and the greater landscape to determine the relative availability of nest sites in the study area using Kruskall-Wallis nonparametric equivalent of the ANOVA. We considered $P<0.1$ as statistically significant to be conservative and to avoid type II errors (e.g. Schmiegelow et al. 1997, Irons et al. 2000).

\section{Classification of forest cover}

A digital version of the Alberta Vegetation Inventory (AVI) was assembled for the study area using ArcInfo 8.3 GIS (Environmental Systems Research Institute, Redlands, California). The AVI is a vector based inventory developed from 1:15,000 aerial photos and interpreted to a spatial resolution of approximately 1 ha. It contains information on the estimated decade of stand origin, stand height, dominant overstory tree species composition, as well as nonforest vegetation composition and structure. We reclassified AVI classes into eleven variables describing forest structure and composition (Table 2). We used 80 yr as the cutoff between young and old forest, since forest $>80 \mathrm{yr}$ was beyond rotation age in this system.

\section{Nesting territory habitat}

Here we compared nesting habitat at the scale of a territory with that found in areas not used by barred owls within the 80,000 ha study area. The land area of the study area was 30 times as large as the total amount of habitat covered by our owl territories. We created circles of $1000 \mathrm{~m}$ radius with an area of 314 ha centered on nest sites $(n=8)$ and unused sites $(n=21)$ chosen at random across the landscape. The buffer area was chosen to represent the average territory size that we found for owls with $>20$ telemetry relocations $(x=327.2+123.9$ ha, mean \pm SE, $n=6$; Olsen 1999).

\section{Locations within the home range}

A total of 201 locations from four males and four females on different territories were used in the analysis of telemetry locations, presumably foraging or roosting locations within the home range. For each owl, minimum convex polygons were constructed using all of the estimated locations. To define available habitat, we placed a circular buffer of $2000 \mathrm{~m}$ radius, and area of 1256 ha, centered on the geographical center of activity 
for each territory. We located available habitat within this radius instead of inside the actual home range because the number of locations for some owls was small, i.e., range 10-30 locations, and likely underrepresented their range of potential daily movement. In Saskatchewan, in similar habitat, the maximum average home range size for Barred Owls was 1234 ha (Mazur et al. 1998). Random points $(n=194)$ were then generated from a uniform distribution with a minimum separation distance of $100 \mathrm{~m}$ and constrained to the circular buffers. Proportional cover of each cover class was extracted from plots with a radius of $100 \mathrm{~m} \mathrm{(3.14}$ ha) around each radio location and random point. The precision of the radio telemetry locations was approximately 3 ha (Olsen 1999).

\section{Resource selection functions}

We used binary logistic generalized linear models to derive probabilistic resource selection functions (RSF), to represent Barred Owl habitat selection (Manly et al. 1993). Habitat selection functions were developed based on use vs. availability. Model output was the probability $(P)$ that the variable attributes of any given site represented Barred Owl resource selection. For each model variable, we assessed the strength of each predictor covariate on the dependent variable using the $95 \%$ confidence interval of the odds ratio $(\operatorname{Exp} \beta)$. If the confidence interval overlapped one, then we concluded that the variable had poor power and inconclusive statistical inference. Akaike's information criterion differences adjusted for small sample size $\left(\mathrm{AIC}_{c} \Delta\right)$, and Akaike weights $(w)$ were used to assess and select the most parsimonious RSF model.

Based on previous studies of Barred Owl habitat, use we made the following a priori predictions for habitat selection. At the nesting territory scale we expected that owls would not include recent cutblocks (CUT1) and include old forest (OLDCON, OLDDEC) and wet areas (WETLND, WATER, TRDBOG) in their territories. We included wet areas as owls may forage along their edges: some studies noted that they use riparian areas. Within the home range where owls were foraging and roosting, we expected this because they are dietary generalists (Takats 1998, Mazur and James 2000) and, thus, they might use a broader array of habitat types. Hence, in addition to the variables noted above we included younger forest (YNGDEC, YNGCON, CUT2) and deleted variables concerned with wet areas since we expected owls to forage along the edges and not in areas with these features. We did not have an a priori prediction for which combinations of these owls would select for, so we ran models with various combinations of these variables.

\section{RESULTS}

\section{Nest site description}

Ten nests were located: eight in balsam poplar and two in trembling aspen trees. Six nests were in live trees and four were in snags. With the exception of one stick-nest, owls nested in hollow tree cavities. Five nests were located in side-entrance window cavities, and four in top-entrance chimney cavities. Window cavities were formed from broken branches, and chimneys occurred in hollow trunks of trees whose tops had fallen off. The average dbh of trees used for nesting was $51 \mathrm{~cm}$; the smallest nest tree was $34 \mathrm{~cm}$ in diameter (Table 2). Nest trees were significantly larger (Mann-Whitney $U$ test, $U$ $=87, P=0.05)$ and significantly taller $(U=91, P=$ 0.06 ) than random trees (Table 2). The average distance from a nest site to the nearest cut block was $292 \mathrm{~m}$, and half were within $50 \mathrm{~m}$ of a cut block.

\section{Nest site selection}

Nests were embedded in sites that had much higher densities of large $>34 \mathrm{~cm}$ dbh deciduous snags $(\beta$ $=0.08)$ and higher shrub height $(\beta=0.24)$ than random sites in the territory (Table 2, stepwise logistic regression: $P=0.004)$. The AUC value from ROC analysis was 0.82 , suggesting that the model was reasonably good at discriminating used from random nest sites. Variables positively correlated with large deciduous snags were total snag basal area $(r=0.69, P=0.00)$, understory density $(r=$ $0.34, P=0.03$ ), density of balsam poplar trees with $\mathrm{dbh}>38 \mathrm{~cm}(r=0.42, P=0.007)$, and basal area of balsam poplar snags $(r=0.73, P=0.00)$. Hence, nest sites were in areas with a high density of dead and live large poplars: in other words, old poplar stands with corresponding high density of understory shrubs and trees. 


\section{Nest site availability}

Since Barred Owls chose large diameter snags in which to nest, and nest trees were located in stands with high densities of large diameter, i.e., $>34 \mathrm{~cm}$ dbh, deciduous snags, we compared the distribution of large-diameter snags at three spatial scales: nest sites, unused sites within the home range, and across the landscape. Nest sites had fewer small-diameter snags and a greater number of large-diameter snags compared with unused and landscape sites. Snags used for nesting by owls ranged from 34-77 cm dbh (Table 2). Therefore, we assumed that the minimum diameter for a potential nest site was $34 \mathrm{~cm} \mathrm{dbh}$. We calculated the availability of potential nest sites by counting number of snags $\geq 34 \mathrm{~cm}$ dbh at nest sites, random sites within the home range, and the landscape. This measure of snag availability was then converted to density, i.e., snags/ha. Snag density was highest at nest sites, lower at random sites within the home range, and lowest on the landscape $(x$ and $95 \%$ CI, $(n): 26.7,17.3,(n=10)$; 7.5, 3. 6, $(n=30) ; 3.2,2.4(n=44)$, respectively (Kruskal-Wallis test, $\chi 2=17.7, d f=2, P<0.001$ ).

\section{Nesting territory habitat}

At the nesting territory scale, owls used a variety of habitats (Table 3), primarily young deciduous forest, old conifer and deciduous mixedwood, recent cutblocks, and treed bog. At this scale and compared to the larger landscape, resource selection was positively correlated with the proportional area of recent cutblocks and old conifer mixedwood (Tables 4 and 5). The resource selection function for habitat selection at this scale is:

$$
W(\mathrm{x})=\operatorname{Exp}\left(0.126^{*} \mathrm{CUT} 1+0.083^{*} \mathrm{OLDCON}-3.474\right)
$$

\section{Locations within home ranges}

Within their home ranges, owls used a variety of habitats (Table 3), primarily young deciduous forest, treed bog, old coniferous and deciduous mixedwood and wetland for foraging and roosting. Although amount of cutblock was low within home ranges (Table 3), owls selected for cutblocks > 30yr old and against recent cutblocks, i.e., $<30 \mathrm{yr}$ old (Table 4 and 5). They also selected for young, i.e., $<$ 80-yr old, deciduous mixedwood, old conifer mixedwood, and against old, i.e., > $80 \mathrm{yr}$, deciduous mixedwood (Table 4 and 5). The resource selection function is:

$$
\begin{aligned}
& W(\mathrm{x})=\operatorname{Exp}\left(0.012^{*} \text { YNGDEC }+0.007^{*} \mathrm{OLDCON}+\right. \\
& \left.0.036^{*} \mathrm{CUT} 2-0.005^{*} \mathrm{OLDDEC}-0.011^{*} \mathrm{CUT} 1-0.619\right)
\end{aligned}
$$

\section{DISCUSSION}

The status of the Barred Owl as an old-growth indicator is at least partly supported by our results. Some elements of old-growth forest were essential for Barred Owl nesting in our study area. In particular Populus trees with a minimum diameter of $34 \mathrm{~cm}$ were used for nesting. In the boreal mixedwood ecoregion, aspen and poplar trees represent 69-91\% of the available snags, depending on age of the stand (Lee 1998). Barred Owls' apparent preference for deciduous trees for nesting may thus reflect availability, or perhaps the fact that they are susceptible to decay. Unlike conifers, deciduous trees may remain standing for a long time when rotten (Petersen and Petersen 1992). Characteristics of nest trees used in our study are similar to nesting sites described by others (Haney 1997, Mazur et al. 1997, Postupalsky et al. 1997, Leder and Walters 1980, Takats 1998, Buchanan et al. 2004). Three studies that reported mean cavity tree diameter and height found a range of mean $\mathrm{dbh}$ from 47-61 cm and heights from $6.8-13.4 \mathrm{~m}$ (reported in Mazur and James 2000). The mean dbh in our study was $51.6 \mathrm{~cm}$ and height was $16 \mathrm{~m}$, consistent with other studies.

We found no studies on Barred Owl nest sites that considered the characteristics of the area immediately surrounding the nest. In our area, nest trees were embedded in patches of old mixedwood forest with a high density of large dead, $>34 \mathrm{~cm}$ $\mathrm{dbh}$, and live balsam poplars, dbh $>38 \mathrm{~cm}$, with high shrub understory. Nest trees that are surrounded by a high density of large diameter snags and trees may be less obvious to predators (Martin and Roper 1988) and, if the nest is depredated, the owl can quickly find an alternative nest tree within the patch. Alternatively, Barred Owls may choose nest sites within old forest patches to provide cover and food for young. Barred Owl young leave the nest at $28-35 \mathrm{~d}$, when they are flightless, remain 
Table 3. Percent cover in each cover class for nesting habitat at the nesting territory scale scale $(n=8)$ and at owl locations $(n=201)$ within home ranges. Refer to cover classes given in Table 1.

\begin{tabular}{lllll}
\hline \hline Cover class & $\begin{array}{l}\text { Mean \% cover at } \\
\text { nesting territory scale }\end{array}$ & $\begin{array}{l}\text { Range of \% cover at } \\
\text { nesting territory scale } \\
\text { scale }\end{array}$ & $\begin{array}{l}\text { Mean \% cover at owl } \\
\text { locations in home } \\
\text { ranges }\end{array}$ & $\begin{array}{l}\text { Range of \% cover at owl } \\
\text { locations in home ranges }\end{array}$ \\
\hline OLDDEC & 11.0 & $3-35$ & 9.1 & $0-100$ \\
OLDCON & 17.5 & $2-39$ & 15.5 & $0-100$ \\
YNGDEC & 31.4 & $2-63$ & 35.2 & $0-100$ \\
YNGCON & 1.5 & $0-5$ & 0.7 & $0-52$ \\
TRBOG & 12.7 & $0-41$ & 18.6 & $0-100$ \\
PINE & 0.7 & $0-4$ & 5.0 & $0-83$ \\
WETLND & 1.9 & $0.1-4$ & 7.5 & $0-100$ \\
WATER & 0.0003 & $0-1$ & 1.3 & $0-46$ \\
ANTHRO & 1.3 & $0-3$ & 0.9 & $0-37$ \\
CUT1 & 21.7 & $0-54$ & 4.7 & $0-98$ \\
CUT2 & 0.4 & $0-3$ & 1.4 & $0-64$
\end{tabular}

within the nest patch prior to dispersal, and after fledging are fed and protected by the parents for several months (Bird and Wright 1977). Olsen (1999) followed radio-tagged fledged juveniles from two broods for ten weeks: they remained in older forest in predispersal home ranges of 3 and 20 ha.

Despite selection of old forest for nesting, Barred Owls did not appear to completely avoid anthropogenic disturbance, as suggested by others (Bosakowski 1994, Laidig and Dobkin 1995). Half of the nests were located within $50 \mathrm{~m}$ of a cutblock edge. The smallest patch, i.e., 1.7 ha, used for nesting was a "habitat island" isolated by harvesting while the hen was on eggs. In another case, an owl nested in a 15 ha patch surrounded by a 1-yr-old clear-cut. In both these situations, owls nested successfully, but the nest patch was not occupied in subsequent years. In Appalachia, Barred Owl nests were closer to forest clearings than random sites (Devereux and Mosher 1984), and owls nested in small patches (6-33 ha; Haney 1997). In Saskatchewan, Mazur et al. (1997) found Barred Owl nests within $25 \mathrm{~m}$ of roads. Hence, it appears that Barred Owls can nest close to forest clearings as long as suitable nest trees are available. However, more information is required on population demography to determine whether Barred Owls can persist in small patches in landscapes managed for forestry.

Barred Owl selected nesting territories with more old conifer-dominated mixedwood and recent cutblocks than found across the landscape, although they contained a wide variety of habitat types and ages (Table 3). However, owls selected against recent cutblocks during foraging within the home range suggesting that apparent selection of cutblocks at the territory scale may be an artifact of the fact that recent harvesting occurs in older mixedwood stands. Hence, nesting territories may contain recent harvesting, and birds will nest near it, but do not use it for foraging and roosting. We 
Table 4. Akaike's information criterion scores (AICc), AICc weights $(w)$ and number of parameters $(k)$ for candidate habitat models developed for barred owl habitat selection at the nesting territory and home range scales. Selected models are shown in bold.

\begin{tabular}{lccc}
\hline \hline Model & $k$ & AICc & $w$ \\
\hline Nesting territory scale & & & \\
CUT1 + OLDCON + WETLND + OLDDEC + WATER + TRBOG & 6 & 113.81 & $<0.001$ \\
CUT1 + OLDCON + WETLND + OLDDEC + WATER & 5 & 58.23 & $<0.001$ \\
CUT1 + OLDCON + WETLND + OLDDEC & 4 & 40.56 & $<0.001$ \\
CUT1 + OLDCON + WETLND & 3 & 32.40 & 0.04 \\
CUT1 + OLDCON & $\mathbf{2}$ & $\mathbf{2 7 . 3 7}$ & $\mathbf{0 . 5 2}$ \\
CUT1 & 1 & 27.72 & 0.44 \\
Telemetry locations within home ranges & & & 0.187 \\
YNGDEC + OLDCON + OLDDEC + CUT2 + CUT1 + YNGCON & 6 & 620.21 & $\mathbf{0 . 5 4 1}$ \\
YNGDEC + OLDCON + OLDDEC + CUT2 + CUT1 & $\mathbf{5}$ & $\mathbf{6 1 8 . 0 8}$ \\
YNGDEC + OLDCON + OLDDEC + CUT2 & 4 & 620.26 & 0.182 \\
YNGDEC + OLDCON + OLDDEC & 3 & 624.05 & 0.027 \\
YNGDEC + OLDCON & 2 & 623.02 & 0.046 \\
YNGDEC & 1 & 625.07 & 0.016 \\
& & &
\end{tabular}

should be cautious in interpreting this result, however, since only $7 \%$ of the total landscape had been recently harvested. Mazur et al. (1998) found that Barred Owl breeding home ranges in Saskatchewan had greater proportions of old mixedwood forest $(\geq 80 \mathrm{yr}$ ), and low proportions of young forest $(<50 \mathrm{yr})$ and treed muskeg than the landscape overall. Although active harvesting was occurring in their study area, recent cutblocks were not differentiated from young forest, so a direct comparison with our study cannot be made.

Unlike other studies (e.g., Bosakowski 1994), Barred Owls in our area did not require large expanses of unfragmented forest for foraging and roosting. Barred Owls are dietary generalists (Johnsgard 1988, Mazur and James 2000) and can forage in a variety of habitat types and ages. In our study area they used several habitat types within their home ranges, including open areas such as old cutblocks and wetland. At this scale, they had a positive association with young deciduous mixedwood, old conifer mixedwood, and old regenerating cutblocks (> $30 \mathrm{yr}$ ) and a negative association with recent cutblocks and old deciduous mixedwood. In Saskatchewan, however, Barred Owls strongly selected old mixedwood for foraging and roosting, with weaker selection for mature mixedwood and deciduous forests (Mazur et al. 1998). Differences between studies may reflect differences in forest classification and amount of harvesting on the landscape. 
Table 5. Summary statistics for the most parsimonious habitat models for Barred Owl nesting territory and home range scales. With the listed variables, coefficients $(B)$, standard errors (SE), degrees of freedom $(d f)$, odds ratios $(\operatorname{Exp}(B))$, and $95 \%$ confidence intervals $(\mathrm{CI})$ are included.

\begin{tabular}{lcccccc}
\hline \hline & $B$ & SE & $d f$ & $P$ & $\operatorname{Exp}(B)$ & $95 \%$ CI for EXP $(B)$ \\
\hline Nesting territory scale & & & & & & \\
CUT1 & 0.126 & 0.055 & 1 & 0.023 & 1.135 & $1.018,1.265$ \\
OLDCON & 0.083 & 0.043 & 1 & 0.055 & 1.086 & $0.998,1.182$ \\
Constant & -3.474 & 1.190 & 1 & 0.004 & 0.031 & \\
Telemetry locations in home ranges & & & & & \\
YNGDEC & 0.012 & 0.003 & 1 & 0.000 & 1.012 & $1.006,1.018$ \\
OLDCON & 0.007 & 0.004 & 1 & 0.087 & 1.007 & $0.999,1.015$ \\
OLDDEC & -0.005 & 0.004 & 1 & 0.259 & 0.995 & $0.988,1.004$ \\
CUT1 & -0.011 & 0.005 & 1 & 0.049 & 0.989 & $0.979,1.000$ \\
CUT2 & 0.036 & 0.019 & 1 & 0.056 & 1.036 & $0.999,1.075$ \\
Constant & -0.619 & 0.187 & 1 & 0.001 & 0.538 & \\
& & & & & &
\end{tabular}

\section{CONCLUSION}

We provide the following recommendations for the conservation of Barred Owls in managed forest landscapes in boreal mixedwood forests. These are based on a small sample of birds, hence should be regarded as preliminary. Actions should be implemented in an adaptive management framework, accompanied by long-term monitoring of owls.

1. Maintain potential nest trees (Populus snags and live trees) $>34 \mathrm{~cm}$ dbh in patches of large balsam poplar $(\mathrm{DBH}>38 \mathrm{~cm}$; minimum 30 stems/ha) and deciduous snags (> $34 \mathrm{~cm} \mathrm{dbh}$; minimum 23 stems/ha). Since few snags will remain in retention patches 30-60 yr after harvesting, additional patches containing young and mature trees should be retained to allow recruitment into older age classes as regeneration proceeds. We suggest that the patches be 10-20 ha in size, based on average patch size where nests were located ( 9 ha; Olsen 1999) and the upper home range size of predispersal juveniles (20 ha; Olsen 1999). Studies of snag production and recruitment are required to provide information on potential nest site availability at various stages of forest succession and under different harvesting regimes and silvicultural practices. In addition, studies on minimum size of patch required to successfully nest and produce independent young are required.

2. Maintain a heterogeneous landscape around nest patches, consisting of young $(<80 \mathrm{yr})$ deciduous mixedwood, old ( $>80 \mathrm{yr})$ conifer and deciduous mixedwood, treed bogs, wetlands, and regenerating cutblocks $>30 \mathrm{yr}$ old. Ranges of these values for the owls in our study are found in Table 3. Although birds 
in our study remained in landscapes that had been partly clear-cut, they avoided recent cutblocks for foraging and roosting. Hence, some tracts of land without recent cutblocks should be retained: a minimum of 300 ha for breeding, based on breeding home range size, and larger for the nonbreeding period (1200 ha based on nonbreeding home range size of Barred Owls in Saskatchewan (Mazur et al. 1998). Older forest patches could be produced by extended rotations or by using "floating reserves" (Kneeshaw and Gauthier 2003). More research is required to determine minimum patch sizes for retaining Barred Owls and to determine how much recent clear-cutting can be tolerated by the owls in the home range.

Responses to this article can be read online at:

http://www.ace-eco.org/voll/iss3/artl/responses/

\section{Acknowledgments:}

We thank G. Hayward, F. K. A. Schmiegelow, and S. Dyer for their comments on a previous version of this manuscript. R. Sissons, D. Stepnisky, and C. Burgess deserve recognition for their hard work and dedication to the study from its inception. $M$. Piorecky, C. McCallum, and M. Kroetsch also provided valuable support in and out of the field. We are grateful to Mike Norton for providing his vegetation data. Logistical support and forest inventory data were provided by Alberta Pacific Forest Industries, Pearson-Timberline Forestry Consultants, and Weyehaeuser Canada. Funding was provided by the Manning Diversified Forest Products Trust Fund, Natural Sciences and Engineering Research Council of Canada, Alberta Sports Recreation Parks and Wildlife Foundation, Canadian Forest Service, Sustainable Forest Management Network, and Alberta Pacific Forest Industries.

\section{LITERATURE CITED}

Bird, D. M., and J. Wright. 1977. Apparent distraction display by a Barred Owl. Canadian Field-Naturalist 91:176-177.
Bonan, G. B., and H. H. Shugart. 1989. Environmental factors and ecological processes in boreal forests. Annual Review of Ecology and Systematics 20:1-28.

Bosakowski, T. 1994. Landsat reveals negative effect of forest fragmentation on Barred Owl distribution. Records of New Jersey Birds 20:66-70.

Bosakowski, T., R. Smeiser, and J. Benzinger. 1987. Distribution, density, and habitat relationships of Barred Owl in northern New Jersey. Pages 135143 in R. W. Nero, R. J. Clark, R. J. Knapton, and R. H. Hamre, editors. Biology and Conservation of Northern Forest Owls: Symposium Proceedings. U. S. Forest Service General Technical Report RM-142, Rocky Mountain Forest and Range Experimental Station, Fort Collins, Colorado, USA.

Bosakowski, T., and D. G. Smith. 1998. Response of a forest raptor community to broadcasts of heterospecific and conspecific calls during the breeding season. Canadian Field Naturalist 112:198-203.

Buchanan, J. B., T. L. Fleming, and L. L. Irwin. 2004. A comparison of barred and spotted owl nestsite characteristics in the eastern Cascade Mountains, Washington. Journal of Raptor Research 38:231-237.

Cumming, S. G., P. J. Burton, S. Prahacs, and M. R. Garland. 1994. Potential conflicts between timber supply and habitat protection in the boreal mixedwood of Alberta, Canada: a simulation study. Forest Ecology and Management 68:281-302.

Dark, S. J., R. J. Gutierrez, and G. I. Gould. 1998. The Barred Owl (Strix varia) invasion in California. Auk 115:50-56.

Devereux, H. G., and J.A. Mosher. 1984. Breeding ecology of Barred Owls in the central Appalachians. Journal of Raptor Research 18:49-58.

Elody, B. I., and N. F. Sloan. 1985. Movements and habitat use of Barred Owls in the Huron Mountains of Marquette County, Michigan, as determined by radio telemetry. Jack Pine Warbler 63:3-8.

Guetterman, J. H., J. A. Burns, J. A. Reid, R. B. Horn, and C. C. Foster. 1991. Radio telemetry methods for studying Spotted Owls in the Pacific 
Northwest. U.S. Forest Service General Technical Report PNW-GTR-272. Department of Agriculture, Forest Service, Pacific Northwest Research Station, Portland, Oregon, USA.

Haney, J. C. 1997. Spatial incidence of Barred Owl (Strix varia) reproduction in old-growth forest of the Appalachian plateau. Journal of Raptor Research 31:241-252.

Herter, D. R., and L. L. Hicks. 2000. Barred owl and spotted owl populations and habitat in the central Cascade Range of Washington. Journal of Raptor Research 34:279-286.

Hess, G. R., and T. J. King. 2002. Planning open spaces for wildlife I. Selecting focal species using a Delphi survey approach. Landscape and Urban Planning 58:25-40.

Irons, D. B., S. J. Kendall, W. P. Erickson, L. L. McDonald, and B. K. Lance. 2000. Nine years after the Exxon Valdez oil spill: effects on marine bird populations in Prince William Sound, Alaska. Condor 102: 723-737.

James, P. C. 1993. Old growth and owls: What have we learned? Pages 70-79 in D. H. Kuhnke, editor. Birds in the boreal forest. Proceedings of a workshop held March 10-12, 1992 in Prince Albert, Saskatchewan. Forestry Canada, Northern Forestry Centre, Edmonton, Alberta, Canada.

Johnsgard, P. A. 1988. North American owls: biology and natural history. Smithsonian Institution Press, Washington, D.C., USA.

Johnson, D. H. 1980. The comparison of usage and availability measurements for evaluating resource preference. Ecology 61:65-71.

Kelly, E. G., E. D. Forsman, and R. G. Anthony. 2003. Are Barred Owls displacing spotted owls? Condor 105:45-53.

Kie, J. 1994. CALHOME. Available online at: http ://nhsbig.inhs.uiuc.edu/wes/home range.html.

Kirk, D.A., and C. Hyslop. 1998. Population status and recent trends in Canadian raptors: a review. Biological Conservation 83:91-118.

Kneeshaw, D., and S. Gauthier. 2003. Old growth in the boreal forest: a dynamic perspective at the stand and landscape level. Environmental Review 11:S99-S114.

Laidig, K. J., and D. S. Dobkin. 1995. Spatial overlap and habitat associations of Barred Owls and great horned owls in southern New Jersey. Journal of Raptor Research 29:151-157.

Leder, J. E., and M. L. Walters. 1980. Nesting observations for the Barred Owl in western Washington. Murrelet 61:110-112.

Lee, P. 1998. Dynamics of snags in aspendominated midboreal forests. Forest Ecology and Management 105:263-272.

Manly, B. F. J., L. L. McDonald, and D. L. Thomas. 1993. Resource selection by animals: statistical design and analysis for field studies. Chapman Hall, New York, New York, USA.

Martin, T. E., and J. J. Roper. 1988. Nest predation and nest-site selection of a western population of the hermit thrush. Condor 90:51-57.

Mazur, K. M., S. D. Frith, and P. C. James. 1998. Barred Owl home range and habitat selection in the boreal forest of central Saskatchewan. Auk 115:746754.

Mazur, K. M., P. C. James, and S. D. Frith. 1997. Barred Owl nest site characteristics in the boreal forest of Saskatchewan, Canada. In J. R. Duncan, H. D. Johnson and T. H. Nicholls, editors. Biology and Conservation of Owls of the Northern Hemisphere: Second International Symposium, Pages 267-271. U.S. Forest Service General Technical Report N-190. U.S. Dept. of Agriculture, Forest Service, North Central Forest Experiment Station, St. Paul, Minnesota, USA.

Mazur, K. M., and P. C. James. 2000. Barred Owl (Strix varia). In A. Poole and F. Gill, editors. Birds of North America. Number 508. Academy of Natural Sciences, Philadelphia, Pennsylvania, USA, and American Ornithologists' Union, Washington, D.C., USA. Available online at: http:/ /bna.birds.cornell.edu/BNA/.

Nicholls, T. H., and D. W. Warner. 1972. Barred Owl habitat use as determined by radiotelemetry. Journal of Wildlife Management 36:213-224.

Olsen, B. 1999. Breeding habitat ecology of the 
Barred Owl (Strix varia) at three spatial scales in the boreal mixedwood forest of north-central Alberta. Dissertation. University of Alberta, Edmonton, Alberta, Canada.

Olson, G. S., R. G. Anthony, E. D. Forsman, S. H. Ackers, P. J. Loschl, J. A. Reid, K. M. Dugger, E. M. Glenn, and W. J. Ripple. 2005. Modeling of site occupancy dynamics for northern spotted owls, with emphasis on the effects of Barred Owls. Journal of Wildlife Management 69:918-932.

Petersen, E. B., and N. M. Petersen. 1992. Ecology, management and use of aspen and balsam poplar in the prairie provinces, Canada. Forestry Canada, Northern Forestry Centre Special Report Number 1, Edmonton, Alberta, Canada.

Postupalsky, S., J. M. Papp, and L. Scheller. 1997. Nest sites and reproductive success of Barred Owls (Strix varia) in Michigan. Pages 325-337 in J. R. Duncan, H. D. Johnson, and T. H. Nicholls, editors. Biology and Conservation of Owls of the Northern Hemisphere: Second International Symposium. U. S. Forest Service General Technical Report N-190. U.S. Dept. of Agriculture, Forest Service, North Central Forest Experiment Station, St. Paul, Minnesota, USA.

Rubino, M. J., and G. R. Hess. 2003. Planning open spaces for wildlife 2: modeling and verifying focal species habitat. Landscape and Urban Planning 64:89-104.

Schmiegelow, F. K. A., and S. J. Hannon. 1993. Adaptive management, adaptive science and the effects of forest fragmentation on boreal birds in northern Alberta. Pages 584-598 in R. E. McCabe, editor. Transactions of the 58th North American Wildlife and Natural Resources Conference. March 1993, Washington, D.C. Wildlife Management Institute, Washington, D.C., USA.

Schmiegelow, F. K. A., C. S. Machtans, and S. J. Hannon. 1997. Are boreal birds resilient to fragmentation? An experimental study of shortterm community responses. Ecology 78:19141932.

Schneider, R. R., J. B. Stelfox, S. Boutin, and S. Wasel. 2003. Managing the cumulative impacts of land uses in the Western Canadian Sedimentary Basin: a modeling approach. Conservation Ecology 7:8.
Strong, W. L., and K. R. Leggat. 1992. Ecoregions of Alberta. Alberta Forestry, Lands and Wildlife, Edmonton, Alberta, Canada.

Swets, J. A. 1988. Measuring the accuracy of diagnostic systems. Science 240:1285-1293.

Takats, D. L. 1998. Barred Owl habitat use and distribution in the Foothills Model Forest. Dissertation. University of Alberta, Edmonton, Alberta, Canada. 